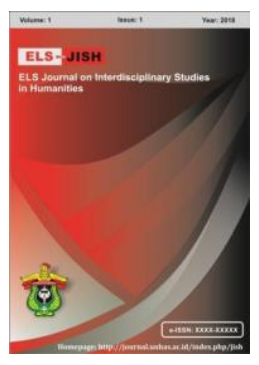

ELS-JISH

ELS Journal on Interdisciplinary Studies on Humanities

Volume 3 Issue 2, 2020

ISSN (print) : 2621-0843

ISSN (online) : 2621-0835

Homepage : http://journal.unhas.ac.id/index.php/jish

\title{
Factors Affecting the Effectiveness of Inter-Dialectical Accommodation among the Sellers-Buyers Discourse
}

\author{
Abdul Muhid', Hamzah A. Machmoed ${ }^{2}$, Abdul Hakim Yassi $^{3}$, Nasmilah$^{4}$ \\ 19abdul.muhid09@gmail.com
}

\begin{abstract}
In this research, the researchers convince the readers about factors that affecting the effectiveness of Inter-dialectical accommodation among sellers-buyers. In this research, they prove how the theory of Giles cannot cover the discourse among sellers and buyers in terms of accommodation, which is done in Central Lombok Nusa Tenggara Barat Province. The researchers describe the phenomenon of the inter-dialectical accommodation in the dialect of Meno-mene versus Meriak-meriku. The object of this research is the activities of sellers-buyers in doing the transaction in the market. The data in this research is taken through observation, recording, interview and note taking of the accommodation among sellers and buyers discourse in some markets in Praya Barat, Praya and Jonggat Sub-district. The researchers use the interpretative qualitative method with some data to reflect the condition of sellers versus buyers discourse in the market. The researchers find the preliminary data shows that the Giles Convergence Theory is un-effective or not applicable in the market where sellers and buyers of Meno-mene versus Meriak-meriku assemble and do a transaction. However, the research result shows the un-effectiveness or there is no effect of converging in bargaining. This research reveals that the convergence theory by Giles cannot be generalized into all part of the discourse, especially in the dialect of Meno-mene versus Meriak-meriku.
\end{abstract}

Keywords: Accommodation, Convergence, Discourse, Inter-dialectal Accommodation, Giles Accommodation Theory.

How to cite: Muhid, A., et al. (2020). Factors Affecting the Effectiveness of Inter-Dialectical Accommodation among the Sellers-Buyers Discourse. ELS Journal on Interdisciplinary Studies in Humanities, 3(2), 170-178. DOI: 10.34050/els-jish.v3i2.10264

\section{Introduction}

The developing of science and knowledge in this era affects all aspect of a human being. For instance, the way they interact with other people, and also a lifestyle. Especially, in social knowledge, the researchers find many things to happen and including the sociolinguistics. In this research, the researchers collect some phenomenon to be analyzed dealing with the inter-dialectical accommodation in the dialect of Meno-mene versus Meriak-meriku, and through the appearance of the data found, they revisit the theory by Giles about Communication Accommodation theory (CAT) encompasses convergence. The concept of convergence in communication among societies is very crucial, as

${ }^{1}$ Universitas Bumigora, Indonesia

${ }^{234}$ Universitas Hasanuddin, Indonesia 
they intensively interact among others, and it will help them to avoid hard negotiation. Thus, this strategy of communication is believed to be such an effective way to succeed in negotiation. The effectiveness of convergence has been proved in several prior-researches, such as in abroad and in Indonesia.

The first research on the dialectology was done in Lombok by Teeuw (1951). He applies field research method and the result of the study was published with title Dialect Atlas van Lombok. The idea of him was very popular among researchers, and it is applied up to the present to see the geographical dialect around Indonesia. The current research will also apply a similar method as proposed by prior researcher Teeuw, but specifically, the current research adopts the technique of listening, participating, interviewing and recording. However, the current research mainly focuses on revisiting the universality of convergence among two dialects between meriak-meriku and meno-mene which are used by sellers and buyers in central Lombok. Hence, the similarity from the prior research is a method of collecting data, and the difference is at the object and location of research. In the current research, the researcher will directly participate in the field of research to assure the validity of the data required. Therefore, he maximally exists at the location where the social interaction.

Society is a small part of the community in the world that always does interaction among them. The people do interact with their communities and even with society from different background and different dialect. They associate among others through the interaction. As people know that they interact directly face to face and communicate the idea with language. Also, the language as the gift to human is used to convey the message (Rahman \& Letlora (2018). The interesting phenomenon whilst they interact one to another with different dialect they can keep the conversation. Nevertheless, the speaker of one dialect may converge to another dialect or they keep using their own dialect and it is so called accommodation. The accommodation in communication among people in the world is indispensable. Remembering that language and society are continuums of the civilization of the entire time, this has happened all over the world.

In a simple word, that accommodation in communication is a strategy to minimize conflict in transferring the idea to the interlocutor. The readers mostly believe that through communication the transfer idea will be much simpler and easy to be understood. The difference in pronouncing the word sometimes may become a problem in communication. Thus, in this way, the speakers of different dialect will find the best way to communicate their own ideas. In sociolinguistics, especially dialect Giles (1973) emphasized that convergence will help people of different dialect to meet the goal of communication.

Here, the researchers discuss how the inter-dialectical accommodate the speakers of different dialect in the conversation. Dialect itself discusses the variation of language in society. Since it is empirical knowledge, then the data is language fact that can be observed and also verified. This research belongs to macro linguistics which covers interdisciplinary, for dialect studies across linguistic, such as sociology, anthropology, and sociolinguistics. In dialectology, 
it is closely related to regional and language social. In fact, the use of it is the contrast seen in the market among sellers and buyers discourse.

\section{Method}

This research is a sociolinguistics study and deals with the social phenomenon. Here the researchers employ the appropriate design for this research is qualitative interpretative research with the symbolic approach. The total subject used in this research is ten sellers-buyers from meriaq-meriku and meno-mene dialect. But, here the researchers simply present some parts of the data taken. Since the sellers-buyers in the market is very large, then the researchers use purposive sampling, while the object of this research is accommodation among sellers-buyers of people from meriaq-meriku while interaction in the market. Much deeper this research encompasses the convergence among them. Basically, the data used in the qualitative research are taken through several activities and interactions in our daily life, like; birthday party, meeting, religious ceremonies, social processes and another group of the community, as recommended by Saville - Troike (2003). Since these activities provide very natural data deals with social interactions amongst people. The idea is also supported by Miriam (2015) that the natural data can be gained through an interview in social activities consciously or unconsciously.

Hence, the primary data for this research is collected through factual dialog in daily communication in the market, particularly buyers-sellers discourse. and the data gains through three steps such as; observation, recording, interviewing the documentation is as a compliment. The information is collected, clarified and sort it based on the need for the research. The researchers apply interpretative qualitative analysis..

\section{Findings and Discussion}

The appearance of convergence in communication is to twinset the harmony among actors of communication, depending on the target of speaking. So, the speakers should smoothly find way and style. Several things can lead people to converge in communication, such as; first, both speaker and hearer own the same beliefs on something, second, they possess the same personality, and the third, at least they have the same background (Yasir, 2011: 204).

In interaction, people are not only spoken the words but also involving all things including the mimic and gesture. Therefore, to suit the communication among them, they need a strategy of communication, for instance, convergence. In this case, the speaker will justify the words, behavior to be similar or more likely to the hearer, Giles, and Smith (1979). Later, West and Turner (2008: 224) also gave a similar idea to the prior expert.

The conversation or dialogue in the market included several backgrounds of buyers like students, civil servant or government officers, and farmers. Here, the data found will be shown as a way it is. It tries to display data naturally as data taken on the spot. As had been proposed by Saville-Troike (2003) that taking data naturally will be quite complicated. But, in this study, the data will be taken through recording, and interview as natural as possible. Later, Labov 
(2010) also emphasized on the secret interview to eliminate the interviewer paradox.

There are two data samples presented in the result and discussion to cover the problem questioned:

Table 1. Dialogue between Seller/buyer ${ }^{\star}$ )

\begin{tabular}{|c|c|c|}
\hline $\begin{array}{l}\text { Seller/ } \\
\text { buyer }\end{array}$ & Dialogues & Translation \\
\hline$S$ & $\begin{array}{lcll}\text { Silak } & \text { pak, } & \text { napi } & \text { kayunm } \\
-a d v & n-v o c & \text { Pron (qw) } & v t \text {-want }\end{array}$ & $\begin{array}{l}\text { Please sir, what do you } \\
\text { want? }\end{array}$ \\
\hline B & 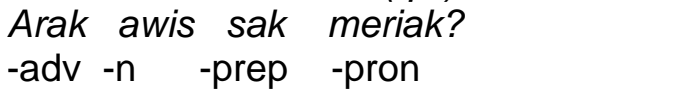 & Is there a sickle like this? \\
\hline $\mathbf{S}$ & $\begin{array}{l}\text { enggih... arakn, kloekn skukn ya } \\
\text {-adj-conv...-adv - det unmark -pron } \\
\text { semeton, aneh Pilek } \\
\text { n-count -adv -v }\end{array}$ & $\begin{array}{l}\text { Yes there is, here you } \\
\text { are, just choose }\end{array}$ \\
\hline B & $\begin{array}{lrr}J i & \text { pirekh } & \text { pak? } \\
-\mathrm{n} & \text {-pron } & n-v o c\end{array}$ & How much? \\
\hline S & $\begin{array}{lll}\text { Pire lalokn, bait } & \text { wah } & R p .35 .000 \\
\text { Un-mark } & \text {-vt } & \text { n-imper }\end{array}$ & $\begin{array}{l}\text { Not much, take it for } \\
\text { Rp. } 35.000\end{array}$ \\
\hline B & $\begin{array}{l}\text { Hmmmm, pacuan segerahn? } \\
\text {-fil } \quad \text { adv adv }\end{array}$ & $\begin{array}{l}\text { Hmmm, really? } \\
\text { Yes, you like take it }\end{array}$ \\
\hline $\mathbf{S}$ & \begin{tabular}{lllll} 
enggih, & mum & \multicolumn{2}{c}{ baniq bait } & wah \\
-adj-conv & -conj & -vt & -vt & n- imper
\end{tabular} & Sorry, if so \\
\hline B & $\begin{array}{l}\text { Sabar mentokn } \\
\text {-adj -conj }\end{array}$ & \\
\hline
\end{tabular}

*) Data 1 - (Date : 19-05-2018, Location: Renteng Market, Buyer (B): Supri (32), Buncalang, Seller (S): Hafazah (50), Berembeng

In the conversation above, a buyer is a man with 32 years old of age and speaks meriak-meriku dialect. The seller tries to start the conversation to attract the buyer's attention. He only addresses the candidate of the buyer by saying Pak. This is the common ways for a seller to begin the conversation. The seller starts with a polite word of napi. This word is usually spoken by meno-mene people. The readers can see that the buyer is quite friendly to the candidate of the buyer. He tries to address his buyer with a polite address. This kind of seller shows his ability to attract the buyer by pretending to be more polite. It can be seen through the language he used, even he/she is not a nobleman but still helshe uses a polite diction like a noble. More the (S) expresses the language through meriak-meriku dialect: kloekn skukn ya. In this way, the (S) accommodate the buyer by using (B) dialect. In order, he can sell the item to (S). In the following table, the researcher shows the differences of dialect and lexical. 
Table 2. The Differences of Dialect and Lexical

\begin{tabular}{|c|c|c|c|}
\hline No & Meno-mene & Meriak-meriku & Meaning \\
\hline 1 & $\begin{array}{lccc}\text { Silak } & \text { pak, } & \text { napi } & \text { kayunm } \\
- \text {-adv } & n-v o c & \text { pron }(q w) & \text { vt- }\end{array}$ & $\begin{array}{l}\text { apek milikm amak/wayah } \\
\text { Pron (qw) vt- p.pron }\end{array}$ & $\begin{array}{l}\text { What do you } \\
\text { want, sir? }\end{array}$ \\
\hline 2 & $\begin{array}{lrc}\text { Loekn } & \text { aing } & n e \\
\text { Det (qty) } & \text { unmark } & \text {-det(d.pron) }\end{array}$ & 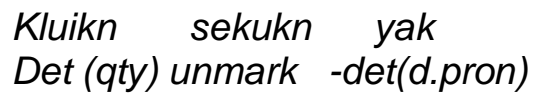 & $\begin{array}{l}\text { Many, here } \\
\text { you are }\end{array}$ \\
\hline 3 & $\begin{array}{l}\text { Tetu, Mase mahel lalok? } \\
\text {-adv -adv -adj -int }\end{array}$ & $\begin{array}{l}\text { Pacuan, Segerahn kemaheln? } \\
-a d v \text {-adv -adj -int }\end{array}$ & $\begin{array}{l}\text { Really, what } \\
\text { expensive } \\
\text { price }\end{array}$ \\
\hline
\end{tabular}

At the beginning of the conversation, the word napi indicates that the word which is expressed refers to a person that speaks meno-mene dialect and also to make the language more polite or we can say that the word napi is indicating honorific expression. The word napi is also usually to engage the interlocutor in speaking. The seller knows how to respect others. But, after the buyer speaks out his word, everything starts to change. Let's see how the seller responds to the buyer, even still he is being a good seller by saying enggih. Spontaneously, the seller changes his dialect follows the buyer's dialect. Nevertheless, the researcher can still identify that he is not a real person of meriak-meriku. Because he just adapts the word merely not the intonation. Further, (Bell, 1984; Coupland, 1984) emphasize on interaction is also applied by the speakers to endorse the interlocutor's understanding. While Jenkins (2000) added another factor that makes communication more comprehensible is that the capability of the speakers to adjust their speech pattern. Another explanation related to this is proposed by Giles and Coupland (1988) in their theory of Communication Accommodation Theory that explains every communicator wants the communication should run smoothly, whether by minimizing the distinction or maintain the distinctiveness from the speaker.

In the conversation above, the seller tries to accommodate or converge to the buyer's dialect in the order he will get more attention. In line with Clark (1996.3) mentions that the interaction in societies is common sense because they are a social being who always involve in activities. Therefore, the individual often adjusts his language or dialect depends on the interlocutor or partner of speaking. Along with the interaction, people try to accommodate each other to make a comprehensible message and easy to be understood by the interlocutor. But in the conversation above, the reader can see at the end of the conversation, the buyer left the seller without buying the thing. From a simple analysis, the seller belongs to Bidder this type will justify any means to get the lowest price according to his wishes. He will bid the price of an item at an unreasonable price. It is triggered by the response from the seller that the buyer feels mocked by the seller because he feels that the seller puts the wrong intonation on words he spokes out.

The details reason after the researcher confirms to the buyer, why she leaves the seller are: 1) The seller uses his dialect inappropriately, this makes him not comfortable because he thinks being mocked by the seller, and 2) At 
the closing statement of seller sound quite arrogant by saying the word mum baniq jek bait wah.

On the other hand, even, the seller still uses polite word enggih in the statement, but he puts a little bit arrogant phrases at the end. As a result, the meaning will bear a negative to the hearer. See Faruk (2015) who mentioned the meaning of communication is as a tool of communication to transfer the idea from the speakers to the interlocutors that indicating feelings and thought.

From the simple analysis above, it is seen that the Giles theory for accommodation is not applicable. While he believes that the concept of convergence in communication among societies is very crucial, as they intensively interact among others. And it will help them to avoid hard negotiation. Thus, this strategy of communication is believed to be such an effective way to succeed in negotiation. But, in fact, it is not, and in contrary with Giles (1973) recommended accommodation while interacting, by involving convergence, which can help the hearer to gain the message spoken by the speaker.

From the reasons of the buyer above, the researcher concludes that the factor of un-effective convergence in communication triggered by some issues, such as 1) linguistically because the seller cannot tackle the all parts of opposite dialect to be taken into the convergence. He only imitates the lexical of the meriak-meriku dialect without engaging the intonation. 2) Manner and attitude, it is commonly as a big issue in interaction with other people.

Table 3. Manner and Attitude in Interaction**)

\begin{tabular}{|c|c|c|}
\hline $\begin{array}{l}\text { Seller/ } \\
\text { buyer }\end{array}$ & Dialogues & Translation \\
\hline B & 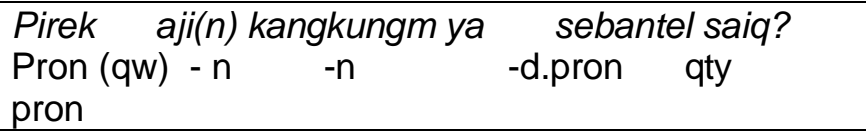 & $\begin{array}{l}\text { How much is the water } \\
\text { spinach? }\end{array}$ \\
\hline $\mathbf{S}$ & $\begin{array}{l}\text { nggeh silak, pilek wah juluk nike } \\
\text {-adj-conv adv vt imper unmark pron }\end{array}$ & Please, Just choose \\
\hline B & $\begin{array}{l}\text { Maukth aji } 1000 \text { sebantel ne? } \\
\text { mod } \quad \text { qty } \quad \text { d.pron }\end{array}$ & $\begin{array}{l}\text { Ca I have them a bunch for } \\
\text { a thousand?. }\end{array}$ \\
\hline $\mathbf{S}$ & $\begin{array}{l}\text { Kangkung bawak tiye semeton, aneh hak lek } \\
n \quad \text { prep d.pron } n \text {-count adv } \\
\text { pron prep } \\
\text { kiri }(m) \text { tiye bait wah aji } 3 \text { seribu. } \\
\text { Adj d.pron vt imper } n\end{array}$ & $\begin{array}{l}\text { They are imported brother, } \\
\text { you can take three for one } \\
\text { thousand on your left side. } \\
\text { Note: imported means the } \\
\text { water spinach not taken } \\
\text { from central Lombok as } \\
\text { usually. }\end{array}$ \\
\hline B & $\begin{array}{l}\text { Nyerek lalokn bede aji(n) nok, semeno bai aneh } \\
\quad \text { adj int adj n unmark d.pron } \\
\text { prep adv }\end{array}$ & $\begin{array}{l}\text { How come it is different, I } \\
\text { will take it with that price }\end{array}$ \\
\hline $\mathbf{S}$ & $\begin{array}{l}\text { Anuk mahel tendakn gamak ton } \\
\text { pre.det adj } \mathrm{n} \quad \text { unmark n-count }\end{array}$ & The capital is high \\
\hline B & $\begin{array}{l}\text { Ndekm mele jarien } \\
\text { neg } \\
\text { vt }\end{array}$ & You don't want \\
\hline $\mathbf{S}$ & $\begin{array}{l}\text { Pete sak lainan wah silak } \\
\text { vt pron pron int adv }\end{array}$ & Find another \\
\hline
\end{tabular}


Data 2 - (Date : 19-05-2018, Location: Renteng Market, Buyer (B): Luthfiana (39) Sukarara, and Seller (S): Iq.Emi (47), Semayan Praya

Let's see the conversation above, the candidate of the buyer comes from Sukarara that the people use dialect of Meriak-meriku, while the seller comes from Semayan that uses Meno-mene dialect in the interaction.

The buyer (B) starts the conversation by saying the sentence: "Pirek aji(n) kangkungm ya sebantel saiq?" this sentence shows that speaker is from meriak-meriku dialect. While the reader compares to the dialect of meno-mene the sentence becomes: "pire jak kangkung hak ne sebantel,bi?. These two sentences show different dialect between the (B) and the (S). From the conversation above, it can be seen that the (B) tries to converge with the (S) in the next sentence of her. See sentence row 3 in the table above. The real sentence of the (B) in the daily life is "bauwfn ji 1000 ya sebantel?, but in this conversation, the (B) converges base on the (S) dialect as in the table above: "Maukth aji 1000 sebantel ne? still, the convergence continues to the end of the conversation. Another example is also seen in the following sentences: Nyerek lalokn bede aji(n) nok, semeno by aneh, Ndekm mele jarien ne aji semeno.

In the above interaction, the researcher sees that (B) is quite sensitive with the statement from (S), (B) sees it is like a stimulus for her to adjust the dialect base on the interlocutor (S). However, the statement from (S) signals to the (B). This phenomenon shows to us that there is an accommodation between the seller and buyer, is that (B) converges to (S). Basically, people tend to adapt or adjust their communication to the interlocutor. The stimuli may come from the first speaker and or from the second speaker. It depends on how the speaker views the moment and goal of interaction. It is in line with what Judee Burgoon (1995) proposed about an Interpersonal Adaptation Theory. Here, researcher displays some differences:

Table 4. An Accommodation between the Seller and Buyer

\begin{tabular}{|c|c|c|c|}
\hline No & Meno-mene & Meriak-meriku & Meaning \\
\hline 1 & Ajian pire jak kangkung ne & Pirek aji(n) kangkungm ya & $\begin{array}{c}\text { How much is this water } \\
\text { spinach }\end{array}$ \\
\hline 2 & $\begin{array}{c}\text { "Maukth aji } 1000 \text { sebantel } \\
\text { ne?. }\end{array}$ & $\begin{array}{c}\text { bauwfn ji } 1000 \text { ya } \\
\text { sebantel? }\end{array}$ & $\begin{array}{c}\text { Can I have it } 1000 \text { per } \\
\text { bind }\end{array}$ \\
\hline
\end{tabular}

The theory of Burgoon (1995) states that while the speaker enters the interaction at all kinds of topic, for sure he/she brings his/her own desires, expectation and requirements. Thus, in the conversation or in the interaction the speaker tries to adapt the others, in the order he/she can determine whether the conversation ends or continues positively or not. The equal statement also has explained by Giles (1973) that people tend to do accommodation to ease communication, and minimize the difficulties in reaching the goal of communication. The accommodation or convergence done by $(B)$ in the interaction above also tells us about human needs in social life. Besides, she (B) is a human being can possess a similar idea with the person she talks to. 
Besides that human being tend to find and respond to the other actors in interaction. The form of respond may appear in many forms. It depends on the stimuli they perceive.

Even though $(B)$ continuously practicing $(\mathrm{S})$ dialect, still she cannot meet her goal. Thus, the phenomenon in this conversation proves that the Giles' theory about accommodation/convergence in communication cannot be applied in this situation. Meaning, the theory of Giles is not universally applicable to all convergence activities. Since the end of convergence is negative or in contrary to Giles that proposes by doing convergence communication will be more effective and efficient.

\section{Conclusion}

The effectiveness of communication cannot rely totally on accommodation. How well the buyer or and the seller converge among others in the communication does not guarantee they will meet a positive end of the communication. Concept of convergence in communication among societies is very crucial, as they intensively interact among others. And it will help them to avoid hard negotiation. Thus, this strategy of communication is believed to be such an effective way to succeed in the negotiation. But, in fact, it is not, and it is in contrary to Giles (1973) convergence, which can help the hearer to gain the message spoken by the speaker.

Based on the research analysis, the researchers conclude that: 1) Both speakers of different dialect do convergence in the conversation, they try to imitate the dialect of their interlocutors as similar as possible, but they still miss things that cannot afford the target of communication, and 2) Event they adopt the interlocutor's dialect and use it as very similar word as the native of its dialect, but they fail to keep attitude and manner, still they cannot confirm or lower the price in the market.

Meaning that, from simple conclusion above the factor of un-effective convergence in communication triggered by some issues, such as: Linguistically, because the seller cannot tackle the all parts of opposite dialect to be taken into the convergence. He only imitates the lexical of the meriak-meriku or meno-mene dialect without engaging the intonation. Manner and attitude, it is commonly as a big issue in interaction with other people.

Abbreviation: Adv : adverb, $\mathrm{N}$ : noun, $\mathrm{n}$-voc: noun voice of consumer, pron: pronoun, Pron (qw): pronoun (question word), Vt: verb of transitive, Det (qty) : determiner (quantity), D.pron: demonstrative pronoun, Adj: adjective, Int: intensifier, Mod: modal, Prep: preposition, n-count: noun-countable, imper: imperative, pre.det: predeterminer

\section{References}

Burgoon, J. (1995). Interpersonal Adaptation Theory

Clark, H. (1996). Using Language. Cambridge: Cambridge University Press

Coupland, N. (2007). Style Language Variation and Identity. Cambridge University Press

Fasold, R. (1984). The Sociolinguistics of Society. Oxford: Blackwell 
Fegurson, C. A. (1996). Socio-Linguistic Perspectives: Paper on Language in Society, 1959-1994

Fishman, J. A. (1991). Reversing Language Shift: Theoretical and Empirical Assistance to Threatened Languages. Clevedon: Multilingual Matters.

Fishman, J. (1972). Domains and the relationship between micro-and macrosociolinguistics in John J. Gumperz \& Dell Hymes (Eds.) Directions in sociolinguistics: The ethnography of communication, (pp. 435-453), New York, Holt,Rinehart and Winston.

Howard, G., Nikolas, C., Justine, C. (1991). Accommodation Theory: Communication, Context, and Consequence. ICambridge: Cambridge University Press; 1991. pp. 1-68.

Kamwangamalu, N. M. (2003). Social change and language shift, 225-243

Labov, W. (2010). Principles of Linguistic Change. Cognitive and Cultural Factors. Wiley Blackwell. https://doi.org/10.1002/97814443274964

Liliweri, A. (2009). Makna Budaya dalam Komunikasi Antarbudaya. Yogyakarta: LkiS Printing Cemerlang.

Rahman, F. \& Letlora, P. S. (2018). Cultural Preservation: Rediscovering the Endangered Oral Tradition of Maluku (A Case Study on Kapata of Central Maluku. Advances in Language and Literary Studies. 9(2). pp. 91 - 97.

Teeuw, A. (1951). Dialect-Atlas van/of Lombok (Indonesia). Djakarta: Biro Reproduksi Djawatan Topografi

West, R \& Turner,H,L.(2008). Pengantar Teori Komunikasi: Analisis dan Aplikasi, $3^{\text {th }}$ ed. Jakarta: Salemba Humanika

Yasir.(2009). Pengantar ilmu Komunikasi. Pekan Baru: Pusat Pengembangan Pendidikan.

. (1996b). National Sociolinguistic Profile Formulas in W. Bright (Ed.) Sociolinguistics, 309-315. The Hague: Mputon.

.(2005). Prasangka dan konflik: Komunikasi Lintas Budaya Masyarakat Multikultur.Yogyakarta: LkiS Pelangi Askara Yogyakarta Oxford Univeeristy Press. . (1999). Handbook of Language and Ethnic Identity. Oxford. 